\title{
Polymorphism of blood protein and meat quality of pigs from a mass population
}

\author{
Koćwin-Podsiadła Maria ${ }^{1}$, Jolanta Kuryl ${ }^{2}$ and W. Przybylski ${ }^{1}$ \\ ${ }^{1}$ Agriculture Pedagogical High School, Prusa 12,08-110 Siedlce, ${ }^{2}$ Institute of Animal Genetics \\ and Breeding, Jastrzębiec, 05-551 Mroków, Poland
}

(Recevied 20 January 1992; accepted 1 June 1992)

\begin{abstract}
The investigations carried out on 626 growing pigs were designed to differentiate the extent to which the decreased quality of their meat resulted from the environmental conditions and that to which it was due to the genetic predispositions of the animals. The latter were evaluated on the basis of the presence of the Phi, Po2 and Pgd genes linked with the gene of halothan susceptibility to stress. The quality classes of meat were estimated by measurements of $\mathrm{pH}_{1}$ and the IMP/ATP ratio $\left(\mathrm{R}_{1}\right)$. The genotypes of the animals were determined on the basis of blood erythrocyte enzymes, phosphohexoisomerase (Phi) and phosphogluconate dehydrogenase (Pgd) and of the blood plasma protein, postalbumin-2 (Po2). There were $283 \mathrm{Phi}^{\mathrm{B}}-\mathrm{Po} 2^{\mathrm{S}}-\mathrm{Pgd}^{\mathrm{A}}$ and $\mathrm{Phi}^{\mathrm{B}}-\mathrm{Po} 2-\mathrm{Pgd}^{\mathrm{B}}$ haplotypes which amounted to $22.6 \%$ of their total number. The frequency of occurrence of the two haplotypes specified above in the configuration Phi-Po2-Pgd was the highest in pigs producing the PSE type of meat $(45.7 \%)$, lower in animals with the DFD type of meat $(30.3 \%)$ and the lowest in the group of pigs with normal meat (17.2\%). Animals which produced PSE and DFD meat amounted to $37 \%$ of the examined population, whilst among them, $31.8 \%$ demonstrated genetic predispositions to meat defects.
\end{abstract}

KEY WORDS: pigs, stress, meat quality

\section{INTRODUCTION}

Susceptibility of pigs to stress is a genetically determined characteristic. Most frequently it is examined by the halothane test, i.e. inhalation performed with a mixture of the anaesthetic halothane (fluothane) and oxygen. For that reason the gene determining susceptibility to stress has been called halothane gene. Another method of assessing genetic susceptibility to stress is based on the determination of blood protein polymorphism. Genes which determine this polymorphism are located on the same chromosome as the halothane gene acid in its immediate vicinity (Archibald and Imlah, 1985). The non-random occurrence of certain protein types together with the halothane gene $\left(\mathrm{Hal}{ }^{n}\right)$ is 
a consequence of that linkage. It has been found that over $80 \%$ of animals homozygotic for that allele demonstrate PSE and DFD meat (Barton-Gade and Olsen, 1987). On the other hand it is possible to predict with highly significant probability the occurrence of abnormal muscle tissue on the basis of haplotypes, i.e. of certain configurations of alleles in the system of linked loci Phi-Po2-Pgd. The haplotypes $\mathrm{Phi}^{\mathrm{B}}-\mathrm{Po} 2^{\mathrm{S}}-\mathrm{Pgd}^{\mathrm{A}}$ and $\mathrm{Phi}^{\mathrm{B}}-\mathrm{Po} 2^{\mathrm{S}}-\mathrm{Pgd}^{\mathrm{B}}$ are of particular importance to making prognoses (Koćwin-Podsiadła et al., 1989).

The purpose of this paper was to study to what extent the quality of pig meat depends on the genetic predispositions estimated by the frequency of genes linked with the stress susceptibility gene and to what extent it results from the unfavourable influence of many environmental factors.

\section{MATERIAL AND METHODS}

The experiments were carried out on 626 pigs selected at random from agricultural farms in the region of breeding and production of the Polish Landrace in the eastern part of Poland. The animals were transported to the slaughter-house from distances of about 4080 kilometres. The commercial pre- and slaughter procedure was as follows: resting time prior to slaughter: $24 \mathrm{~h}$; stunning with electric current $160220 \mathrm{~V}, 0.5$ to $0.8 \mathrm{~A}$ and $2500 \mathrm{~Hz}$ during $8 \pm 2 \mathrm{sec}$.; time from stunning to the start of bleeding (in hanging position) up to $40 \mathrm{sec}$. Samples of peripheral blood were taken during slaughter and of the muscle tissue from the longissimus dorsi muscle, behind the last thoracic vertebra. The genotypes of the animals in regard to the genes which control blood proteins - phosphohexoisomerase (Phi), phosphogluconate (Pgd) and postalbumin-2 (Po2) were determined by the electrophoretic technique of Gahne and Junei (1985).

The quality of fresh meat was evaluated by the inosine monophosphate/adenosine triphosphate nucleotide ratio IMP/ATP $\left(R_{1}\right)$, as reported by Honikel and Fischer (1977), and by the measurement of the value 45 minutes ,post-mortem". Quality classes of meat were based on the border values for the $\mathrm{pH}_{1}$ and $\mathrm{R}_{1}$ criteria, according to the Honikel and Fischer (1977) method, modified by Koćwin-Podsiadła et al. (1988):

$\begin{array}{lcc}\text { quality class of meat } & \mathrm{pH}_{1} & \mathrm{R}_{1} \\ \text { PSE } & <6.0 & \geqslant 1.092 \\ \text { partially PSE } & <6.0 & <1.092 \\ \text { normal } & \geqslant 6.0 & <1.092 \\ \text { DFD } & \geqslant 6.0 & \geqslant 1.092\end{array}$

The genetic equilibrium of the experimental material was determined according to the Hardy-Weinberg law. The number of pigs with the determined 
Phi-Po2-Pgd haplotypes in which the abnormal meat was found was expressed as a percentage.

\section{RESULTS AND DISCUSSION}

The mean vaiues of the characteristics used as quality criteria of porcine meat and the frequency of occurrence of animals having abnormal muscle tissue are presented in Table 1 . Of the 626 experimental animals, $37.2 \%$ demostrated meat

TABLE 1

Mean values and standard deviation of meat quality traits in pigs $(n=626)$

\begin{tabular}{|l|c|c|c|c|}
\hline \multirow{2}{*}{ Traits } & \multicolumn{4}{c|}{ Meat class } \\
\cline { 2 - 5 } & PSE & Partial PSE & Normal & DFD \\
\hline No of pigs & 47 & 110 & 393 & 76 \\
$\mathrm{pH}_{1}$ & $5.69 \pm 0.20$ & $5.77 \pm 0.17$ & $6.37 \pm 0.22$ & $6.33 \pm 0.22$ \\
$\mathrm{R}_{\mathbf{l}}$ & $1.238 \pm 0.09$ & $0.961 \pm 0.06$ & $0.891 \pm 0.07$ & $0.183 \pm 0.07$ \\
\hline
\end{tabular}

with PSE and DFD symptoms. This percentage is similar to that found by many authors in pigs from various parts of Poland as well as in pigs bred in the same region (Koćwin-Podsiadła and Kuryl, 1990). From the genetic point of view the experimental material was in equilibrium as described by the Hardy-Weinberg law (Table 2).

TABLE 2

The distribution of phenotypes Phi, Po2 and Pgd in pigs classified according to meat quality

\begin{tabular}{|c|c|c|c|c|c|c|c|c|c|}
\hline \multirow{3}{*}{ Locus } & \multirow{3}{*}{$\begin{array}{c}\text { Pheno- } \\
\text { types }\end{array}$} & \multicolumn{8}{|c|}{ Meat class } \\
\hline & & \multicolumn{2}{|l|}{ PSE } & \multicolumn{2}{|c|}{ Partial PSE } & \multicolumn{2}{|c|}{ Normal } & \multicolumn{2}{|c|}{ DFD } \\
\hline & & $\begin{array}{l}\text { observed/ } \\
\text { expected }\end{array}$ & $x^{2}$ & $\begin{array}{c}\text { observed/ } \\
\text { expected }\end{array}$ & $x^{2}$ & $\begin{array}{l}\text { observed/ } \\
\text { expected }\end{array}$ & $x^{2}$ & $\begin{array}{l}\text { observed/ } \\
\text { expected }\end{array}$ & $x^{2}$ \\
\hline Phi & $\begin{array}{c}\text { A } \\
\mathrm{AB} \\
\mathrm{B}\end{array}$ & $\begin{array}{r}0 / 0.80 \\
12 / 10.63 \\
35 / 35.57\end{array}$ & 0.98 & $\begin{array}{c}2 / 1.33 \\
20 / 21.54 \\
88 / 87.13\end{array}$ & 0.46 & $\begin{array}{r}10 / 8.84 \\
97 / 100.22 \\
286 / 283.94\end{array}$ & 0.27 & $\begin{array}{r}2 / 1.09 \\
14 / 16.05 \\
60 / 58.85\end{array}$ & 1.04 \\
\hline Po2 & $\begin{array}{c}\mathrm{F} \\
\mathrm{FS} \\
\mathrm{S}\end{array}$ & $\begin{array}{l}14 / 12.71 \\
21 / 23.46 \\
12 / 10.83\end{array}$ & 0.52 & $\begin{array}{l}57 / 55.45 \\
43 / 45.30 \\
10 / 9.25\end{array}$ & 0.24 & $\begin{array}{r}252 / 251.52 \\
127 / 125.76 \\
14 / 15.72 \\
\end{array}$ & 0.20 & $\begin{array}{l}36 / 33.10 \\
29 / 34.11 \\
11 / 8.78\end{array}$ & 1.58 \\
\hline Pgd & $\begin{array}{c}A \\
\Lambda B \\
B\end{array}$ & $\begin{array}{l}11 / 12.12 \\
26 / 23.49 \\
10 / 11.28\end{array}$ & 0.53 & $\begin{array}{l}37 / 37.00 \\
53 / 53.59 \\
20 / 19.40\end{array}$ & 0.02 & $\begin{array}{r}125 / 123.24 \\
189 / 193.67 \\
79 / 76.08\end{array}$ & 0.25 & $\begin{array}{l}16 / 16.79 \\
40 / 37.86 \\
20 / 21.35\end{array}$ & 0.23 \\
\hline
\end{tabular}

The analysis of frequency of alleles which control the polymorphism of blood proteins Phi, Po 2 and Pgd, determined by genes linked with the halothane gene revealed that allele $\mathrm{Po}^{\mathrm{S}}$ differentiated the particular quality classes of meat to 
TABLE 3

The distribution of alleles Phi, Po2 and Pgd among animals classified according to meat quality

\begin{tabular}{|l|c|c|c|c|c|}
\hline \multirow{2}{*}{ Allele } & \multicolumn{5}{|c|}{ Meat quality } \\
\cline { 2 - 6 } & $\begin{array}{c}\text { PSE } \\
\mathrm{n}=47\end{array}$ & $\begin{array}{c}\text { Partial PSE } \\
\mathrm{n}=110\end{array}$ & $\begin{array}{c}\text { Total } \\
\text { PSE + part.PSE } \\
\mathrm{n}=157\end{array}$ & $\begin{array}{c}\text { Normal } \\
\mathrm{n}=393\end{array}$ & $\begin{array}{c}\text { DFD } \\
\mathrm{n}=76\end{array}$ \\
\hline $\mathrm{Phi}^{\mathrm{A}}$ & 0.13 & 0.11 & 0.11 & 0.15 & 0.12 \\
$\mathrm{Phi}^{\mathbf{B}}$ & 0.87 & 0.89 & 0.89 & 0.85 & 0.88 \\
$\mathrm{Po2}^{\mathrm{F}}$ & 0.52 & 0.71 & 0.66 & 0.80 & 0.66 \\
$\mathrm{Po2}^{\mathrm{S}}$ & 0.48 & 0.29 & 0.34 & 0.20 & 0.34 \\
$\mathrm{Pgd}^{\mathrm{A}}$ & 0.51 & 0.58 & 0.56 & 0.56 & 0.47 \\
$\mathrm{Pgd}^{\mathrm{B}}$ & 0.49 & 0.42 & 0.44 & 0.44 & 0.53 \\
\hline
\end{tabular}

TABLE 4

The distribution of blood protein haplotypes Phi, Po2, Pgd in relation to meat quality

\begin{tabular}{|c|r|r|r|r|r|r|r|r|r|r|}
\hline \multirow{2}{*}{$\begin{array}{c}\text { Haplotypes } \\
\text { Phi-Po2-Pgd }\end{array}$} & \multicolumn{9}{|c|}{ Meat quality } \\
\cline { 2 - 13 } & \multicolumn{2}{|c|}{ PSE } & \multicolumn{2}{c|}{ Partial PSE } & \multicolumn{2}{c|}{$\begin{array}{c}\text { Total } \\
\text { PSE + part. PSE }\end{array}$} & \multicolumn{2}{|c|}{ Normal } & \multicolumn{2}{c|}{ DFD } \\
\cline { 2 - 13 } & $\mathrm{n}$ & $\%$ & $\mathrm{n}$ & $\%$ & $\mathrm{n}$ & $\%$ & $\mathrm{n}$ & $\%$ & $\mathrm{n}$ & $\%$ \\
\hline AFA & 6 & 6.38 & 16 & 7.27 & 22 & 7.00 & 67 & 8.52 & 6 & 3.95 \\
AFB & 4 & 4.25 & 4 & 1.82 & 8 & 2.55 & 30 & 3.82 & 7 & 4.61 \\
ASA & - & & 3 & 1.36 & 3 & 0.96 & 7 & 0.89 & 1 & 0.66 \\
ASB & 2 & 2.13 & 1 & 0.45 & 3 & 0.96 & 13 & 1.65 & 4 & 2.63 \\
BFA & 27 & 28.72 & 84 & 38.18 & 111 & 35.35 & 314 & 39.95 & 46 & 30.26 \\
BFB & 12 & 12.76 & 53 & 24.09 & 65 & 20.70 & 220 & 27.99 & 42 & 27.63 \\
BSA & 15 & 15.96 & 24 & 10.91 & 39 & 12.42 & 51 & 6.49 & 19 & 12.50 \\
BSB & 28 & 29.79 & 35 & 15.91 & 63 & 20.06 & 84 & 10.69 & 27 & 17.76 \\
\hline Total & 94 & 100 & 220 & 100 & 314 & 100 & 786 & 100 & 152 & 100 \\
\hline
\end{tabular}

the greatest extent (Table 3). The frequency of that allele was the highest in the group of pigs with PSE meat and it was more than double the frequency found in pigs with normal meat. In animals of inferior meat quality the frequency of that allele was nearly two times higher in comparison with animals of normal meat. Haplotypes, i.e. appropriate configurations of alleles relating to three linked loci Phi-Po2-Pgd in groups of pigs of various meat quality were estimated in the further course of this study (Table 4). It was found that the frequency of some haplotypes Phi-Po2-Pgd was typical for certain groups of animals. This was mainly so with haplotypes $\mathrm{Phi}^{\mathrm{B}}, \mathrm{Po}^{\mathrm{S}}, \mathrm{Pgd}^{\mathrm{A}}, \mathrm{Phi}^{\mathrm{B}}, \mathrm{Po}^{\mathrm{S}}$ and $\mathrm{Pgd}$ which are linked with the halothane gene (Archibald and Imlah, 1985; Hojny et al., 1985) and lower meat quality (Koćwin-Podsiadła et al., 1989). Those haplotypes are referred to in short as BSA and BSB in the further part of this paper. Their frequency in the group of animals with PSE and DFD symptoms in meat was 
found to be about $45 \%$ and $30 \%$, respectively, and this is about $2 \cdots 3$ times higher than in pigs with normal meat. BFA and BFB haplotype frequencies did not differentiate the animals in relation to their predisposition for production of meat of low technological value since they attained about $50 \%$ in the examined groups (PSE and DFD). The AFA, AFB, ASA and ASB haplotypes demonstrated a low usefulness in predicting the quality of meat due to their low frequency in the experimental material. The lack of linkage of the specified haplotypes with the occurrence of abnormal meat in pigs was found also in the study of Koćwin-Podsiadła et al.(1989).

Among the 1252 identified Phi-Po2-Pgd haplotypes, a total of 283 BSA and BSB haplotypes were found and they were linked to a highly significant degree with the occurrence of anormalous meat: that figure constituted $22.6 \%$ of all of the identified haplotypes (Table 5, point 6). In the group of animals which showed meat with PSE and DFD defects ( $37 \%$ of the examined population), $31.8 \%$ demonstrated genetic predispositions (Table 5, point 4 ). The frequency BSA and BSB haplotypes was the highest in pigs with PSE meat $(45.7 \%)$, slightly lower with PFD meat $(30.3 \%)$ and the lowest in pigs with normal meat $(17.2 \%)$. In the total number of BSA and BSB haplotypes, $52 \%$ were found in the group of animals demonstrating PSE or DFD type of meat (Table 5, point 4).

TABLE 5

The number of pigs in particular meat quality groups in comparison with the frequency of blood protein haplotypes Phi-Po2-Pgd linked with the halothane gene

\begin{tabular}{|c|c|c|c|c|c|c|c|}
\hline \multicolumn{2}{|l|}{ Indices } & \multirow{2}{*}{ PSE } & \multirow{2}{*}{$\begin{array}{l}\text { Partial } \\
\text { PSE } \\
2\end{array}$} & \multirow{2}{*}{$\begin{array}{l}\text { DFD } \\
-3 \\
\end{array}$} & \multirow{2}{*}{$\begin{array}{c}\text { Abnormal } \\
\text { PSE }+ \\
\text { part. PSE } \\
\text { + DFD } \\
4\end{array}$} & \multirow{2}{*}{$\begin{array}{c}\text { Normal } \\
5\end{array}$} & \multirow{2}{*}{$\begin{array}{c}\text { Total } \\
6\end{array}$} \\
\hline & & & & & & & \\
\hline Number of pigs & $\begin{array}{l}\mathrm{n} \\
\%\end{array}$ & $\begin{array}{l}47 \\
7.51\end{array}$ & $\begin{array}{l}110 \\
17.57\end{array}$ & $\begin{array}{l}76 \\
12.14\end{array}$ & $\begin{array}{l}233 \\
37.22\end{array}$ & $\begin{array}{l}393 \\
62.78\end{array}$ & $\begin{array}{l}626 \\
100\end{array}$ \\
\hline $\begin{array}{l}\text { Number of particular } \\
\text { haplotypes }\end{array}$ & $\begin{array}{l}\mathrm{n} \\
\%\end{array}$ & $\begin{array}{l}94 \\
7.51\end{array}$ & $\begin{array}{l}220 \\
17.57\end{array}$ & $\begin{array}{l}152 \\
12.14\end{array}$ & $\begin{array}{l}466 \\
37.22\end{array}$ & $\begin{array}{l}786 \\
62.78\end{array}$ & $\begin{array}{r}1252 \\
100\end{array}$ \\
\hline $\begin{array}{l}\text { Frequency of BSA and BSB } \\
\text { haplotypes in the particular } \\
\text { meat classes }\end{array}$ & $\begin{array}{l}\mathrm{n} \\
\%\end{array}$ & $\begin{array}{l}43 \\
45.75\end{array}$ & $\begin{array}{l}59 \\
26.82\end{array}$ & $\begin{array}{l}46 \\
30.26\end{array}$ & $\begin{array}{l}148 \\
31.76\end{array}$ & $\begin{array}{l}135 \\
17.20\end{array}$ & $\begin{array}{l}283 \\
22.60\end{array}$ \\
\hline $\begin{array}{l}\text { Frequency of BSA and BSB } \\
\text { haplotypes in comparison with } \\
\text { the total number of these } \\
\text { haplotypes }\end{array}$ & $\begin{array}{l}\mathrm{n} \\
\%\end{array}$ & $\begin{array}{l}43 \\
15.20\end{array}$ & $\begin{array}{l}59 \\
20.85\end{array}$ & $\begin{array}{l}46 \\
16.25\end{array}$ & $\begin{array}{l}148 \\
52.30\end{array}$ & $\begin{array}{l}135 \\
47.70\end{array}$ & $\begin{array}{l}283 \\
100\end{array}$ \\
\hline
\end{tabular}


Hovewer, it should be emphasized that 466, i.e. 37.2\% Phi-Po2-Pgd haplotypes were found in pigs with abnormal meat and the remaning $62.8 \%$ in pigs with meat of normal quality (Table 5, point 4 and 5 , respectively).

One hundred forty eight, i.e. $52.3 \%$ of the total number of BSA and BSB haplotypes, were found in the smaller group of pigs which demonstrated abnormal meat (Table 5, point 4). If the same proportion of BSA and BSB haplotypes would appear in all groups of animals, the percentage of haplotypes in the group of pigs with abnormal meat should be respectively lower, i.e. about $30 \%$. This relationship is better confirmed in the experimental findings presented in Figure 1. Among pigs with PSE meat the highest percentage was found in animals having only BSA and BSB $(25.5 \%)$ haplotypes, i.e. ten times higher than in the group of pigs with normal meat $(2.7 \%)$. In the other groups of pigs with abnormal meat (partially PSE or DFD), the number of animals in which only the BSA and BSB haplotypes were identified was more than three times higher in comparison with animals with normal meat (Figure 1). In the group of animals with BSA and BSB haplotypes, there were both stress susceptible and stress resistand pigs.

The haplotypes BSA and BSB may be regarded as typical for pigs having abnormal meat, whereas the BSA and BSB haplotypes had similar frequency in all groups of the examined animals, regardless of the quality of meat (Table 4). If the ,carrier" of the BSA or BSB haplotypes has as its second one the BFA or $\mathrm{BFB}$ haplotype linked with the haplotype gene $\mathrm{Hal}^{n}$, then it is probable that abnormal meat will be produced by such an animal. On the other hand, if the BFA or BFB haplotype is not linked with the halothane gene but with the gene dominant to $\mathrm{Hal}^{n}$, the meat in this case will, most probably, have normal properties. It was found that in heterozygotes $\mathrm{Hal}^{\mathrm{N}} \mathrm{Hal}^{n}$, who are carriers of the recessive $\mathrm{Hal}^{\mathrm{n}}$ allele, lower meat quality was not observed (Sellier, 1987).

\section{CONCLUSIONS}

1. Among alleles linked with the halothane gene, the $\mathrm{Po} 2^{\mathrm{s}}$ allele is the most useful in predicting the quality of porcine meat.

2. The haplotypes BSA and BSB occur with a several times higher frequency in animals having abnormal meat over those with normal meat.

3. Among all Phi-Po2-Pgd haplotypes, the BSA and BSB haplotypes demonstrate the highest usefulness in predicting porcine meat quality since more than half of their total number $(52.3 \%)$ has been found in animals with abnormal meat.

4. Meat obtained from $37 \%$ of the examined animals showed PSE and DFD defects and one third of that group demonstrated genetic predispositions. 


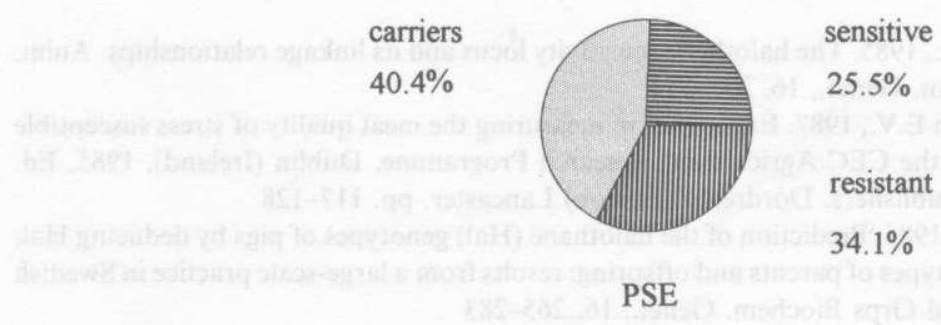

carriers

$35.4 \%$

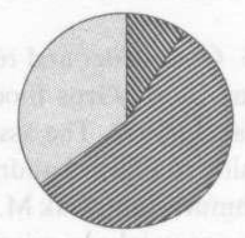

p. PSE

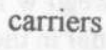

$42.1 \%$

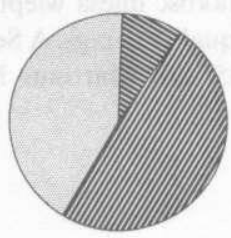

sensitive

$9.2 \%$

resistant

$48.7 \%$

DFD

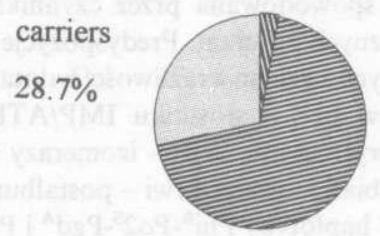

Normal sensitive

$2.7 \%$

resistant

$68.6 \%$

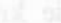

$2.6 \%$

sensitive

$9.1 \%$

resistant

$55.5 \%$

where:

sensitive - animals with the following haplotypes: BSA/BSB, BSB/BSB, BSA/BSA

carriers - animals with the following haplotypes:
a) $\mathrm{BSA} /$ other from $\mathrm{Po} 2 \mathrm{~F}$ or PhiA,
b) $\mathrm{BSB} /$ other from $\mathrm{Po} 2 \mathrm{~F}$ or PhiA,

resistant - animals lacking haplotypes BSA and BSB

Fig. 1 The frequency of speciments with specific haplotypes among animals classified according to meat quality 


\section{REFERENCES}

Archibald A.L., Imlah F., 1985. The halothane sensitivity locus and its linkage relationships. Anim. Blood Grps Biochem. Genet., 16, 253-333

Barton-Gade P.A., Olsen E.V., 1987. Experience in measuring the meat quality of stress susceptible pigs. A Seminar in the CEC Agricultural Research Programme, Dublin (Ireland), 1985, Ed. Martinus Nijhoff Publishers. Dordrecht (Boston) Lancaster, pp. 117-128

Gahne B., Juneya R.K., 1985. Prediction of the halothane (Hal) genotypes of pigs by deducing Hal, Phi, Po2, Pgd haplotypes of parents and offspring: results from a large-scale practice in Swedish breeds. Anim. Blood Grps Biochem. Genet., 16, 265-283

Honikel K.O., Fischer M., 1977. A rapid method for the detection of PSE and DFD porcine muscles. J. Food Sci., 42, 1633-1636

Hojny J., Cepica S., Hradecky J., 1985. Gene order and recombination rates in the linkage groups S-Phi-Hal-(Po2)-Pgd in pigs. Anim. Blood Grps Biochem. Genet., 16, 306-318

Koćwin-Podsiadła M., Kurył J., Dvorak J., 1992. The association between phenotypes of the Phi, Po2 and Pgd system and meat quality in Polish Landrace pigs. Anim. Sci. Pap. Rep. (in press)

Koćwin-Podsiadła M., Zaremba W., Chmura-Janowiak M., 1988. Weryfikacja wartości granicznych $\mathrm{Ph}_{1}$ i IMP/ATP zastosowanych do oceny jakości mięsa wieprzowego. XIX Sesja Naukowa nt.: „Postępy technologii w rozwoju produkcji żywności”, Komitet Techn. i Chemii Żywności PAN, Szczecin 1988, 42

Koćwin-Podsiadła M., Kurył J., 1990. Jakość mięsa wieprzowego w Polsce. Prz. hod., 4/6, 17-20 Sellier P., 1987. Crossbreeding and meat quality in pigs. A Seminar in the CEC Agricultural Research Programme, Dublin (Ireland), 1985, Ed. Martinus Nijhoff Publishers, Dordrecht (Boston) Lancaster, pp. 329-342

\section{STRESZCZENIE}

\section{Polimorfizm białek krwi a jakość mięsa tuczników pogłowia masowego}

Na 626 tucznikach przeprowadzono badania, których celem było określenie, w jakim stopniu obniżona jakość mięsa tuczników jest spowodowana przez czynniki środowiskowe, a w jakim stopniu wynika z predyspozycji genetycznych zwierząt. Predyspozycje te szacowano na podstawie obecności genów Phi, Po2 i Pgd sprzężonych z genem wrażliwości halotanowej na stres. Klasy jakości mięsa ustalono na podstawie kryteriów $\mathrm{pH}_{1}$ i stosunku IMP/ATP $\left(\mathrm{R}_{1}\right)$. Genotypy zwierząt określono w odniesieniu do enzymów erytrocytów krwi - izomerazy fosfoheksozy (Phi) i dehydrogenazy fosfoglukonianu (Pgd) - oraz białka osocza krwi - postalbuminy - 2 (Po2). Wśród 1252 określonych haplotypów znaleziono 283 haplotypy $\mathrm{Phi}^{\mathrm{B}}-\mathrm{Po} 2^{\mathrm{S}}-\mathrm{Pgd}^{\mathrm{A}}$ i $\mathrm{Phi}^{\mathrm{B}}-\mathrm{Po}^{\mathrm{S}}-\mathrm{Pgd}^{\mathrm{B}}$, co stanowiło $22,6 \%$ wszystkich haplotypów. Częstość występowania w/w dwóch haplotypów w układzie Phi-Po2-Pgd była największa u tuczników z mięsem PSE (45,7\%), nieco niższa z mięsem DFD $(30,3 \%)$, a najniższa w grupie z mięsem normalnym (17,2\%). Zwierzęta, których mięso wykazywwało wady PSE i DFD stanowiły $37 \%$ badanej populacji, spośród nich $31,8 \%$ wykazywało predyspozycje genetyczne. 